\title{
The independent association between parathyroid hormone levels and hyperuricemia: a national population study
}

\author{
Janet Y Hui', Jee Woong J Choi ${ }^{1}$, David B Mount ${ }^{2}$, Yanyan Zhu' ${ }^{1}$ Yuqing Zhang ${ }^{1}$ and Hyon K Choi ${ }^{1,3^{*}}$
}

\begin{abstract}
Introduction: Increased frequencies of hyperuricemia and gout have been associated with primary hyperparathyroidism, and recent clinical trials of parathyroid hormone (PTH) have reported hyperuricemic adverse events. We evaluated the potential population impact of PTH on serum uric acid (SUA) levels by using a nationally representative sample of United States adults.

Methods: By using data from 8,316 participants aged 18 years and older in the National Health and Nutrition Examination Survey 2003 to 2006, we examined the relation between serum PTH and SUA levels with weighted linear regression. Additionally, we examined the relation with hyperuricemia by using weighted logistic regression.

Results: SUA levels increased with increasing serum PTH concentration. After adjusting for age, sex, dietary factors, glomerular filtration rate (GFR), and other potentially related biomarkers (calcium, phosphorus, alkaline-phosphatase, 25-hydroxyvitamin D), the SUA level differences from the bottom (referent) to top quintiles of serum PTH levels were $0,8,13,14$, and $19 \mu M(95 \% \mathrm{Cl}, 12$ to $26 ; P$ for trend, < 0.001$)$. These estimates were larger among renally impaired individuals (multivariate SUA difference between the extreme quintiles of PTH, 26 versus $15 \mu M$ among those with GFR $\geq 60$ versus $<60 \mathrm{ml} / \mathrm{min}$ per $1.73 \mathrm{~m}^{2}$, respectively) ( $P$ for interaction $=0.004$ ). The odds of hyperuricemia by various definitions increased with increasing PTH levels as well (multivariate $P$ values for trend, $<$ 0.05).
\end{abstract}

Conclusions: These nationally representative data indicate that serum PTH levels are independently associated with serum uric acid levels and the frequency of hyperuricemia at the population level.

\section{Introduction}

Hyperuricemia is the precursor of gout, a common and painful inflammatory arthritis with a growing disease burden [1]. Hyperuricemia and gout have been long observed to occur with an increased frequency among patients with hyperparathyroidism, whereas parathyroidectomy is known to reduce serum uric acid levels in these cases [2-7]. Elevated parathyroid hormone (PTH) levels are thought to reduce renal urate excretion, although the exact mechanism remains unclear [7]. Furthermore, recent randomized controlled trials have also found that hyperuricemia or gout is associated with use of teriparatride, a recombinant human PTH

\footnotetext{
* Correspondence: hchoius@bu.edu

'The Clinical Epidemiology Unit, Boston University School of Medicine, 650

Albany Street, Suite 200, Boston, MA 02118, USA

Full list of author information is available at the end of the article
}

approved for osteoporotic fracture prevention [8-10]. After cessation of teriparatride, serum uric acid levels decrease [8]. The baseline data of a randomized trial based on men aged $>40$ years [11] and another community population study of men aged $\geq 70$ years [12] showed a significant association between PTH and serum uric acid levels. These data suggest that a significant biologic influence of PTH on serum uric acid level exists, but the impact of this relation at the general population level (including women) is not known. To address this issue, we examined the relation between serum PTH and uric acid levels in a nationally representative sample of men and women (US National Health and Nutritional Examination Survey, NHANES 2003 to 2006).

\section{C) Biomed Central}

(C) 2012 Choi et al.; licensee BioMed Central Ltd. This is an open access article distributed under the terms of the Creative Commons Attribution License (http://creativecommons.org/licenses/by/2.0), which permits unrestricted use, distribution, and reproduction in any medium, provided the original work is properly cited. 


\section{Methods}

\section{Study population}

The NHANES studies are designed to assess the health and nutritional status of adults and children in the United States. These studies are based on a representative sample of the noninstitutionalized US civilian population that is selected by using a multistage, stratified sampling design. The survey is unique in that it combines interviews, physical examinations, and various laboratory data [13]. Beginning in 1999, NHANES became a continuous survey conducted annually with data released in 2-year cycles. In this analysis, we used two recent NHANES datasets that obtained serum PTH levels, the NHANES 2003-2006. After a home interview, participants were invited to attend examination sessions, in which blood and urine specimens were obtained. Our analysis included participants 18 years or older who attended the medical examination, and included the 8,316 participants $(3,961$ men, 4,355 women) with complete information. We repeated our analysis among 8,272 participants, after excluding participants who were taking allopurinol or uricosuric agents $(n=44)$.

The NHANES studies underwent institutional review board approval, and written informed consent was obtained from participants before starting the study.

\section{Measurements}

PTH levels were measured by using the Origen-Electrochemiluminescent analysis (Elecsys 1010 Immunoassay analyzer). The analytic protocols for other serum analytes and laboratory quality-assurance procedures are described in the NHANES Laboratory Procedures Manuals [14]. Values are reported in picomoles per liter, and can be converted to picograms per microliter by dividing by 0.1061 .

Serum uric acid levels were measured by oxidization with the specific enzyme uricase to form allantoin and $\mathrm{H}_{2} \mathrm{O}_{2}$ (Beckman Synchron LX20). Details about qualitycontrol procedures were been published in the NHANES Laboratory Procedures Manuals [14]. Values are reported in micromoles per liter and can be converted to milligrams per deciliter by dividing by 59.48 .

\section{Assessment of covariates}

The NHANES collected information on body measurements (including body mass index (BMI)), medication use (including diuretics, allopurinol, and uricosuric agents), medical conditions (including self-reported hypertension), and relevant laboratory values (serum creatinine, calcium, alkaline phosphatase, phosphorus, and 25-hydroxyvitamin D levels). Glomerular filtration rate (GFR) was estimated by using the Modification of
Diet in Renal Disease study equation: $\operatorname{GFR}\left(\mathrm{m} / \mathrm{min}\right.$ per $\left.\left.1.73 \mathrm{~min}^{2}\right)=186 \times(\text { serum creatinine level }(\mathrm{mg} / \mathrm{dd}))^{-1.154} \times(\text { age })^{-203}\right) \times(0.0742$, if female $) \times(1.212$, if black $)$ [15-17].

The average daily intakes of energy, protein, carbohydrates, sugar, fat, caffeine, and alcohol were derived from a mean of two 24-hour dietary recalls conducted two separate days after the medical examination.

\section{Statistical analysis}

All statistical analyses were computed by using survey commands of STATA (for example, SVYMEAN and SVYREG) to incorporate sample weights and to adjust for clusters and strata of the complex sample design (STATA Corporation, College Station, TX, USA).

We used linear regression modeling to evaluate the relation between PTH levels and serum uric acid levels. PTH levels were categorized into quintiles, and each quintile was compared with the lowest quintile. Multivariate models were adjusted for: age, sex, race, BMI, self-reported hypertension, use of diuretics, use of allopurinol or uricosuric agents, GFR, intake of alcohol, total energy, protein, and sugar, and mutually for serum levels of PTH, calcium, alkaline phosphatase, phosphorus, and vitamin D. To help address the potential influence of central adiposity (reflecting insulin resistance), we conducted analyses with adjustment for waist circumference in addition to, as well as in place of, BMI. Trends in serum uric acid levels across PTH categories were assessed in linear regression models by using continuous PTH values. We performed logistic regression with a dichotomous outcome of hyperuricemia (serum uric acid level $>7.0 \mathrm{mg} / \mathrm{dl}$ in men and $>5.7 \mathrm{mg} / \mathrm{dl}$ in women [18]), adjusting for the same covariates. We also examined the potential impact of alternative definitions of hyperuricemia (serum uric acid level $>6.0 \mathrm{mg} / \mathrm{dl}$ and $>7.0 \mathrm{mg} / \mathrm{dl}$, both regardless of sex) in these regression models.

We examined whether the observed associations persisted within the subgroups stratified by sex, BMI $(<25$ $\mathrm{kg} / \mathrm{m}^{2}$ versus $\left.\geq 25 \mathrm{~kg} / \mathrm{m}^{2}\right)$, GFR $(\geq 60$ versus $<60 \mathrm{ml} /$ min per $1.73 \mathrm{~m}^{2}$ ), serum vitamin D levels $(\geq 52.4 \mathrm{n} M$ (median value) versus $<52.4 \mathrm{n} M$ ), and serum calcium levels $(\geq 2.4 \mathrm{~m} M$ (median value) versus $<2.4 \mathrm{mM}$ ). We determined the statistical significance of potential subgroup effects by testing the significance of interaction terms added to our final multivariate models. For all difference estimates and odd ratios, we calculated 95\% confidence intervals (CIs). All $P$ values are two-sided.

\section{Results}

The mean age of the population was 46 years. The mean serum uric acid level was $319.05 \mu M$ (361 $\mu M$ among men and $280 \mu M$ among women), and $19.13 \%$ were hyperuricemic (20.86\% among men and $17.54 \%$ among 
Table 1 Characteristics according to quintiles of parathyroid hormone (PTH) levels in NHANES 2003-2006 ${ }^{\mathrm{a}}$

\begin{tabular}{|c|c|c|c|c|c|c|c|c|c|c|c|c|c|c|c|c|c|c|}
\hline $\begin{array}{l}\text { Quintiles } \\
\text { of serum } \\
\text { PTH levels, } \\
\text { pM } \\
(\mathrm{pg} / \mathrm{ml})\end{array}$ & $n$ & $\begin{array}{l}\begin{array}{l}\text { Age } \\
\text { (years) }\end{array}\end{array}$ & $\begin{array}{l}\text { Men } \\
(\%)\end{array}$ & $\begin{array}{l}\text { White } \\
(\%)\end{array}$ & $\begin{array}{l}\mathrm{BMI} \\
(\mathrm{kg} / \\
\left.\mathrm{m}^{2}\right)\end{array}$ & $\begin{array}{l}\text { Diuretic } \\
\text { use } \\
(\%)\end{array}$ & $\begin{array}{l}\text { Serum } \\
\text { calcium } \\
(\mathrm{m} M)\end{array}$ & $\begin{array}{l}\text { Serum } \\
\text { vitamin } \\
\text { D } \\
(\mathrm{n} M)\end{array}$ & $\begin{array}{l}\text { Serum } \\
\text { phosphorus } \\
(\mathrm{m} M)\end{array}$ & $\begin{array}{l}\text { Serum } \\
\text { alkaline } \\
\text { phosphatase } \\
\text { (U/L) }\end{array}$ & $\begin{array}{l}\text { Uric } \\
\text { acid } \\
\text { drug } \\
\text { use } \\
(\%)\end{array}$ & $\begin{array}{l}\text { History of } \\
\text { hypertension } \\
\text { (\%) }\end{array}$ & $\begin{array}{l}\text { GFR }(\mathrm{ml} / \\
\operatorname{min~per} \\
\left.1.73 \mathrm{~m}^{2}\right)\end{array}$ & $\begin{array}{l}\text { Alcohol } \\
\text { (g/day) }\end{array}$ & $\begin{array}{l}\text { Total } \\
\text { energy } \\
\text { (kcal/ } \\
\text { day) }\end{array}$ & $\begin{array}{l}\text { Total } \\
\text { protein } \\
\text { (g/day) }\end{array}$ & $\begin{array}{l}\text { Total } \\
\text { sugar } \\
\text { (g/ } \\
\text { day) }\end{array}$ & $\begin{array}{l}\text { Total } \\
\text { caffeine } \\
\text { (mg/ } \\
\text { day) }\end{array}$ \\
\hline $\begin{array}{l}0.6-2.9 \\
(6-27)\end{array}$ & 1,733 & 40 & 47 & 80 & 26.8 & 4.2 & 2.4 & 69.2 & 1.3 & 65.9 & 0.1 & 23 & 96 & 10.9 & 2263 & 87.9 & 129.3 & 185.1 \\
\hline $\begin{array}{l}3.0-3.8 \\
(28-36)\end{array}$ & 1,795 & 44 & 50 & 76 & 27.5 & 4.9 & 2.4 & 63.0 & 1.3 & 66.8 & 0.2 & 28 & 93 & 9.9 & 2179 & 84.3 & 120.8 & 179.3 \\
\hline $\begin{array}{l}3.9-4.7 \\
(37-44)\end{array}$ & 1,462 & 47 & 49 & 75 & 28.3 & 5.7 & 2.4 & 59.4 & 1.3 & 67.0 & 0.1 & 29 & 91 & 9.9 & 2192 & 84.8 & 119.3 & 186.1 \\
\hline $\begin{array}{l}4.8-6.2 \\
(45-59)\end{array}$ & 1,712 & 49 & 47 & 70 & 29.1 & 7.5 & 2.4 & 55.2 & 1.2 & 70.0 & 1.0 & 41 & 89 & 8.5 & 2129 & 83.8 & 117.0 & 157.2 \\
\hline $\begin{array}{l}6.3-52.1 \\
(59-491)\end{array}$ & 1,614 & 51 & 46 & 66 & 30.4 & 14.7 & 2.4 & 49.2 & 1.2 & 74.2 & 1.1 & 48 & 83 & 6.3 & 2009 & 77.2 & 115.0 & 156.7 \\
\hline All & 8,316 & 46 & 48 & 74 & 28.3 & 7.0 & 2.4 & 59.8 & 1.2 & 68.5 & 0.5 & 33 & 91 & 9.2 & 2160 & 83.9 & 120.6 & 173.5 \\
\hline
\end{tabular}

${ }^{\mathrm{a} D a t a}$ are presented incorporating sample weights and adjusted for clusters and strata of the complex sample design of NHANES 2003-2006. ${ }^{\mathrm{b}}$ Allopurinol and uricosuric agents. 
women). The characteristics of the study according to PTH level are shown in Table 1. With increasing PTH levels, age, BMI, serum levels of alkaline phosphatase, use of diuretics and urate-lowering agents, and the frequency of hypertension and diabetes tended to increase, whereas GFR, the proportion of whites, and serum levels of calcium, vitamin D, and phosphorus tended to decrease. Furthermore, intake of total energy, carbohydrates, protein, sugar, fat, and caffeine tended to decrease with increasing PTH levels.

After adjusting for age and sex, serum uric acid levels among individuals in the highest quintile were higher than those in the lowest quintile by $36 \mu M$ (95\% CI, 28 to 44; $P$ for trend, < 0.001). After adjusting for other covariates, the difference was attenuated to $19 \mu M$ (95\% CI, 12 to 26; $P$ for trend $<0.001$ ), but remained significant (Table 2). When we repeated our analyses after excluding participants who were taking allopurinol or uricosuric agents $(n=44)$, the results did not significantly change. When we repeated our multivariate analyses with adjustment for waist circumference, additionally or in place of BMI, our results did not change materially $(P$ values for trend $<0.001)$.

When hyperuricemia was examined as a dichotomous outcome, the relations were similar (Table 3). For example, the multivariate odds ratios (ORs) for hyperuricemia according to increasing quintiles of serum PTH level were $1,1.07,1.22,1.36$, and 1.39 (95\% CI, 1.03 to 1.88 ; $P$ for trend $=0.03)$. Alternative definitions of hyperuricemia (serum uric acid levels $>6.0 \mathrm{mg} / \mathrm{dl}$ and $>7.0 \mathrm{mg} /$ $\mathrm{dl}$, both regardless of sex) did not materially alter these results $(P$ values for trend $<0.03)$.

Additionally, when we stratified our multivariate analysis by subgroups of BMI, GFR, serum vitamin D levels, and serum calcium levels, the association between PTH and serum uric acid levels persisted in all subgroups $(P$ values for trend $\leq 0.007$ ). The association did not vary significantly by these subgroups ( $P$ values for interaction $>0.55$ ) except for GFR subgroups. Serum uric acid levels in individuals of the highest quintile of PTH were higher than in the lowest quintile by $26 \mu M$ ( $P$ for trend $<0.001)$ in the lower GFR group, whereas the corresponding difference was $15 \mu M(P$ for trend $=0.007)$ in the higher GFR group $(P$ for interaction $=0.004)$.

\section{Discussion}

In our nationally representative population study of US men and women, we found that serum uric acid levels and the frequency of hyperuricemia increased with increasing PTH levels in a graded manner. These associations were independent of other risk factors for hyperuricemia, such as age, sex, BMI, waist circumference, dietary risk factors, alcohol intake, renal function, hypertension, diuretic use, and serum levels of calcium and vitamin $\mathrm{D}$. The association persisted across subgroups of BMI, serum levels of calcium, and vitamin D, and was greater in the lower GFR group. These findings provide evidence that supports an independent link between serum PTH and uric acid levels at the national population level.

The mean difference in serum uric acid level between the extreme quintiles of PTH was $19 \mu M(0.31 \mathrm{mg} / \mathrm{dl})$, whereas the difference among individuals with chronic kidney disease (stage 2 or higher) was $26 \mu M(0.43 \mathrm{mg} /$ dl). These levels of adjusted population mean differences were comparable to difference estimates between the extreme quintiles of intakes of total meats or seafood $(0.11 \mathrm{mg} / \mathrm{dl}$ versus $0.10 \mathrm{mg} / \mathrm{dl})$ in another NHANES study [19], which can be translated into a significant risk for incident gout, as demonstrated in a prospective analysis of the Health Professionals Follow-up Study [20]. This potential impact on the eventual risk of gout was also supported by our results with various definitions of hyperuricemia as a dichotomous outcome.

The link between PTH, hyperuricemia, and gout was observed in primary hyperparathyroidism [2-7]. For example, in an NIH case series, 20 of 56 patients (not taking diuretics) had serum uric acid levels $>7 \mathrm{mg} / \mathrm{dl}$

Table 2 Differences in serum uric acid levels according to quintiles of parathyroid hormone in NHANES $2003-2006$

\begin{tabular}{|c|c|c|c|c|c|c|}
\hline $\begin{array}{l}\text { Parathyroid hormone levels } \\
\mathrm{p} M \\
(\mathrm{pg} / \mathrm{ml})\end{array}$ & $\begin{array}{l}\text { Quintile } 1 \\
0.64-2.86 \\
(6-27)\end{array}$ & $\begin{array}{l}\text { Quintile } 2 \\
2.97-3.82 \\
(28-36)\end{array}$ & $\begin{array}{l}\text { Quintile } 3 \\
3.93-4.67 \\
(37-44)\end{array}$ & $\begin{array}{l}\text { Quintile } 4 \\
4.77-6.15 \\
(45-58)\end{array}$ & $\begin{array}{l}\text { Quintile } 5 \\
6.26-52.10 \\
(59-491)\end{array}$ & $P$ value for trend \\
\hline $\begin{array}{l}\text { Age- and sex-adjusted difference, } \mu M \\
\mathrm{mg} / \mathrm{dl}\end{array}$ & 0 (referent) & $\begin{array}{l}8.9(3.3,14.6) \\
0.15(0.05,0.25)\end{array}$ & $\begin{array}{l}15.2(9.1,21.3) \\
0.26(0.15,0.36)\end{array}$ & $\begin{array}{l}20.3(14.0,26.6) \\
0.34(0.24,0.45)\end{array}$ & $\begin{array}{l}35.9(28.0,43.8) \\
0.60(0.47,0.74)\end{array}$ & $<0.001$ \\
\hline $\begin{array}{l}\text { Multivariate difference, }{ }^{a} \mu M \\
\mathrm{mg} / \mathrm{dl}\end{array}$ & 0 (referent) & $\begin{array}{l}7.6(3.0,12.2) \\
0.13(0.05,0.21)\end{array}$ & $\begin{array}{l}12.6(6.7,18.5) \\
0.21(0.11,0.31)\end{array}$ & $\begin{array}{l}14.2(8.6,19.8) \\
0.24(0.14,0.33)\end{array}$ & $\begin{array}{l}22.9(16.3,29.4) \\
0.39(0.27,0.49)\end{array}$ & $<0.001$ \\
\hline $\begin{array}{l}\text { Multivariate difference, }{ }^{b} \mu M \\
\mathrm{mg} / \mathrm{dl}\end{array}$ & 0 (referent) & $\begin{array}{l}7.3(2.9,11.7) \\
0.12(0.05,0.20)\end{array}$ & $\begin{array}{l}13.2(7.4,19.0) \\
0.22(0.12,0.32)\end{array}$ & $\begin{array}{l}14.2(8.9,19.4) \\
0.24(0.15,0.33)\end{array}$ & $\begin{array}{l}18.0(11.4,24.6) \\
0.30(0.19,0.41)\end{array}$ & $<0.001$ \\
\hline $\begin{array}{l}\text { Multivariate difference, }{ }^{c} \mu M \\
\text { mg/dl }\end{array}$ & 0 (referent) & $\begin{array}{l}7.5(2.9,12.2) \\
0.13(0.05,0.21)\end{array}$ & $\begin{array}{l}13.5(7.2,19.9) \\
0.23(0.12,0.34)\end{array}$ & $\begin{array}{l}14.4(9.0,19.8) \\
0.24(0.15,0.33)\end{array}$ & $\begin{array}{ll}18.7 & (11.8,25.7) \\
0.31 & (0.20,0.43)\end{array}$ & $<0.001$ \\
\hline
\end{tabular}

${ }^{\mathrm{a}}$ Adjusted for age, sex, race, body mass index, use of diuretics, allopurinol and uricosuric agents, and hypertension. ${ }^{\mathrm{b}}$ Adjusted for age, sex, race, body mass index, use of diuretics, allopurinol and uricosuric agents, hypertension, serum calcium levels, serum alkaline phosphatase levels, serum phosphorous levels, serum vitamin D levels, and glomerular filtration rate. ' ${ }^{\mathrm{C}}$ Additionally adjusted for total daily intake of alcohol, energy, protein, sugar, and caffeine. 
Table 3 The odds ratios (ORs) of hyperuricemia according to quintiles of parathyroid hormone in NHANES 2003-2006

\begin{tabular}{|c|c|c|c|c|c|c|}
\hline $\begin{array}{l}\text { Parathyroid hormone levels } \\
\mathrm{p} M \\
(\mathrm{pg} / \mathrm{ml})\end{array}$ & $\begin{array}{l}\text { Quintile } 1 \\
0.64-2.86 \\
(6-27)\end{array}$ & $\begin{array}{l}\text { Quintile 2 } \\
2.97-3.82 \\
(28-36)\end{array}$ & $\begin{array}{l}\text { Quintile } 3 \\
3.93-4.67 \\
(37-44)\end{array}$ & $\begin{array}{l}\text { Quintile } 4 \\
4.77-6.15 \\
(45-58)\end{array}$ & $\begin{array}{l}\text { Quintile 5 } \\
6.26-52.10 \\
(59-491)\end{array}$ & $P$ value for trend \\
\hline Age- and Sex-adjusted OR & 1 (referent) & $\begin{array}{l}1.08 \\
(0.77,1.51)\end{array}$ & $\begin{array}{l}1.22 \\
(0.84,1.76)\end{array}$ & $\begin{array}{l}1.54 \\
(1.14,2.08)\end{array}$ & $\begin{array}{l}2.17 \\
(1.62,2.89)\end{array}$ & $<0.001$ \\
\hline Multivariate $\mathrm{OR}^{\mathrm{b}}$ & 1 (referent) & $\begin{array}{l}1.03 \\
(0.75,1.71)\end{array}$ & $\begin{array}{l}1.12 \\
(0.77,1.61)\end{array}$ & $\begin{array}{l}1.29 \\
(0.97,1.71)\end{array}$ & $\begin{array}{l}1.56 \\
(1.165,2.10)\end{array}$ & $<0.001$ \\
\hline Multivariate $O R^{c}$ & 1 (referent) & $\begin{array}{l}1.05 \\
(0.76,1.46)\end{array}$ & $\begin{array}{l}1.18 \\
(0.81,1.74)\end{array}$ & $\begin{array}{l}1.34 \\
(1.02,1.76)\end{array}$ & $\begin{array}{l}1.34 \\
(1.01,1.77)\end{array}$ & 0.03 \\
\hline Multivariate $\mathrm{OR}^{\mathrm{d}}$ & 1 (referent) & $\begin{array}{l}1.07 \\
(0.77,1.49)\end{array}$ & $\begin{array}{l}1.22 \\
(0.81,1.82)\end{array}$ & $\begin{array}{l}1.36 \\
(1.03,1.80)\end{array}$ & $\begin{array}{l}1.39 \\
(1.03,1.88)\end{array}$ & 0.03 \\
\hline
\end{tabular}

${ }^{a}$ Hyperuricemia is defined as having a serum uric acid level $>7.0 \mathrm{mg} / \mathrm{dl}$ for men and $>5.7 \mathrm{mg} / \mathrm{dl}$ for women. ${ }^{\mathrm{b}}$ Adjusted for age, sex, race, body mass index, use of diuretics, allopurinol and uricosuric agents, and hypertension. 'Adjusted for age, sex, race, body mass index, use of diuretics, allopurinol and uricosuric agents, hypertension, serum calcium levels, serum alkaline phosphatase levels, serum phosphorus levels, serum vitamin D levels, and glomerular filtration rate.

${ }^{\mathrm{d}}$ Additionally adjusted for total daily intake of alcohol, energy, protein, sugar, and caffeine.

[3]. After parathyroidectomy, serum uric acid levels decreased by more than $1 \mathrm{mg} / \mathrm{dl}$ in $64 \%$ of these patients [3]. Limited studies have suggested that reduced renal excretion is responsible for the link, but the detailed underlying process remains unknown [7].

Recently, notable advances were made in the physiology of proximal tubular urate transport, with the identification of multiple secretory and absorptive transporters at both the basolateral and apical membranes [21-24]; urate transport across the proximal tubule is the net sum of these two processes. PTH would be expected to have more-negative effects on net proximal tubular urate reabsorption, given that proximal tubular salt $\left(\mathrm{Na}^{+}-\mathrm{Cl}^{-}\right)$and urate transport are regulated in parallel [25] and that PTH is a potent inhibitor of NHE3 [26], a critical apical transporter for proximal tubular salt absorption.

Recent osteoporosis prevention trials of teriparatride as a bone-formation stimulant have also reported hyperuricemia as an adverse event. For example, a clinical trial of 1,637 postmenopausal women found that teriparatride increases the incidence of hyperuricemia in a dose-response fashion, up to $25 \%$ at a dose of $40 \mu \mathrm{g}$ per day $[8,9]$. After cessation of treatment, serum uric acid levels returned to or approached pretreatment levels [8]. However, a randomized trial of men 40 years or older suggested that reducing PTH levels by calcium supplementation may not affect serum uric acid levels [11]. Interestingly, the hyperuricemia adverse events in the teriparatride trial $[8,9]$ were substantially more frequent among renally impaired patients, which was the case in the current population data. These data suggest that renal impairment or its associated processes significantly influence the hyperuricemic effects of $\mathrm{PTH}$, calling for future investigations to elucidate the underlying mechanisms. Furthermore, this raises an intriguing question of whether vitamin $\mathrm{D}$ supplementation in renally impaired patients could help to reduce their serum uric acid levels. Another clinical trial of 428 glucocorticoid-treated adults reported both hyperuricemia $(n=3)$ and gout $(n=1)$ as adverse events of teriparatride, 20 $\mu \mathrm{g}$ per day [10]. Our findings expand these randomized trial data from a specific disease population to a general population level [2-10].

Strengths and limitations of our study deserve comment. This study was performed in a nationally representative sample of US men and women; thus the findings are likely to be generalizable to the US adult population. Although our cross-sectional study alone would leave uncertainty regarding the temporal sequence of exposure-outcome relations and thus about a potential causal link, the aforementioned randomized trial data with dose-response relation and reduction of uric acid levels after cessation of exposure (that is, teriparatride) or after parathyroidectomy in primary hyperparathyroidism, collectively provide a strong causal argument. Thus, our study findings should be viewed as expanding the generalizability of these previous findings to the general population.

Regardless, confirming the relation in a prospective longitudinal observational context (for example, the relation between prior PTH levels and incident gout, particularly in a renally impaired group) would be valuable.

\section{Conclusions}

These nationally representative data indicate that serum PTH levels are independently associated with serum uric acid levels and the frequency of hyperuricemia at the general population level. These data provide support for future studies aimed to clarify the underlying molecular mechanisms.

\section{Abbreviations}

BMl: body mass index; GFR: glomerular filtration rate; NHANES: National Health and Nutritional Examination Survey; PTH: parathyroid hormone; SUA: serum uric acid. 


\section{Acknowledgements}

This work was supported in part by grants from the National Institutes of Health (R01AR056291, P60AR047785).

\section{Author details}

${ }^{1}$ The Clinical Epidemiology Unit, Boston University School of Medicine, 650 Albany Street, Suite 200, Boston, MA 02118, USA. ${ }^{2}$ Renal Division,

Department of Medicine, Brigham and Women's Hospital, Harvard Medical School, 4 Blackfan Circle, Boston, MA 02115 and Nephrology Division, VA Boston Healthcare System, 150 S. Huntington Ave, Boston, MA 02130, USA. ${ }^{3}$ Section of Rheumatology, Boston University School of Medicine, 650 Albany Street, Suite 200, Boston, MA 02118, USA

\section{Authors' contributions}

All authors contributed to studying the concept and design, acquisition of data, analysis and interpretation of data, and critical revision of the manuscript for important intellectual content. JH, JWC, and HC drafted the manuscript, and all authors read and approved the final manuscript.

\section{Competing interests}

Dr. Choi served on advisory boards for Takeda Pharmaceuticals, URL Pharma, and Savient Pharmaceuticals, whereas the other authors have nothing to disclose.

Received: 13 November 2011 Revised: 8 February 2012 Accepted: 10 March 2012 Published: 10 March 2012

\section{References}

1. Zhu Y, Pandya BJ, Choi HK: Comorbidities of gout and hyperuricemia in the US general population: The National Health and Nutrition Examination Survey 2007-2008. Am J Med

2. Mintz DH, Canary JJ, Carreon G, Kyle LH: Hyperuricemia in hyperparathyroidism. N Engl I Med 1961, 265:112-115.

3. Clinical conference: Hyperparathyroidism: recent studies. Ann Intern Med 1973, 79:566-581.

4. Scott JT: Long-term management of gout and hyperuricaemia. Br Med J 1980, 281:1164-1166.

5. Christensson T: Serum urate in subjects with hypercalcaemic hyperparathyroidism. Clin Chim Acta 1977, 80:529-533.

6. Mallette LE, Bilezikian JP, Heath DA, Aurbach GD: Primary hyperparathyroidism: clinical and biochemical features. Medicine (Baltimore) 1974, 53:127-146.

7. Hisatome I, Ishimura M, Sasaki N, Yamakawa M, Kosaka H, Tanaka Y, Kouchi T, Mitani Y, Yoshida A, Kotake H, Shigemasa C, Mashiba H: Renal handling of urate in two patients with hyperuricemia and primary hyperparathyroidism. Intern Med 1992, 31:807-811.

8. Neer RM, Arnaud CD, Zanchetta JR, Prince R, Gaich GA, Reginster JY, Hodsman AB, Eriksen EF, Ish-Shalom S, Genant HK, Wang O, Mitlak BH: Effect of parathyroid hormone (1-34) on fractures and bone mineral density in postmenopausal women with osteoporosis. N Engl J Med 2001, 344:1434-1441.

9. Miller PD, Schwartz EN, Chen P, Misurski DA, Krege JH: Teriparatide in postmenopausal women with osteoporosis and mild or moderate renal impairment. Osteoporos Int 2007, 18:59-68.

10. Saag KG, Shane E, Boonen S, Marin F, Donley DW, Taylor KA, Dalsky GP, Marcus R: Teriparatide or alendronate in glucocorticoid-induced osteoporosis. N Engl J Med 2007, 357:2028-2039.

11. Dalbeth N, Horne A, Gamble GD, Ames R, Mason B, McQueen FM Bolland MJ, Grey A, Reid IR: The effect of calcium supplementation on serum urate: analysis of a randomized controlled trial. Rheumatology (Oxford) 2009, 48:195-197.

12. Nabipour I, Sambrook PN, Blyth FM, Janu MR, Waite LM, Naganathan V, Handelsman DJ, Le Couteur DG, Cumming RG, Seibel MJ: Serum uric acid is associated with bone health in older men: a cross-sectional population-based study. J Bone Miner Res 2011, 26:955-964.

13. NHANES: About the National Health and Nutrition Examination Survery. [http://www.cdc.gov/nchs/nhanes/about_nhanes.htm].

14. NHANES: NHANES 2005-2006 - Lab Methods.[http://www.cdc.gov/nchs/ nhanes/nhanes2005-2006/lab_methods_05_06.htm].
15. Hsu CY, Vittinghoff E, Lin F, Shlipak MG: The incidence of end-stage renal disease is increasing faster than the prevalence of chronic renal insufficiency. Ann Intern Med 2004, 141:95-101.

16. Levey AS, Bosch JP, Lewis JB, Greene T, Rogers N, Roth D: A more accurate method to estimate glomerular filtration rate from serum creatinine: a new prediction equation: Modification of Diet in Renal Disease Study Group. Ann Intern Med 1999, 130:461-470.

17. Levey AS, Greene T, Kusek JW, Beck GJ: A simplified equation to predict glomerular filtration rate from serum creatinine [Abstract]. J Am Soc Nephrol 2000, 11:155A.

18. Centers for Disease Control and Prevention: NHANES III 1988-94 Reference Manuals and Reports (on CD-ROM). Hyattsville, Md: National Center for Health Statistics; 1996.

19. Choi HK, Liu S, Curhan G: Intake of purine-rich foods, protein, dairy products, and serum uric acid level: The Third National Health and Nutrition Examination Survey. Arthritis Rheum 2005, 52:283-289.

20. Choi HK, Atkinson K, Karlson EW, Willett WC, Curhan G: Purine-rich foods, dairy and protein intake, and the risk of gout in men. N Engl J Med 2004, 350:1093-1103.

21. Choi HK, Zhu Y, Mount DB: Genetics of gout. Curr Opin Rheumatol 2010, 22:144-151.

22. So A, Thorens B: Uric acid transport and disease. J Clin Invest 2010, 120:1791-1799.

23. Wright AF, Rudan I, Hastie ND, Campbell H: A "complexity" of urate transporters. Kidney Int 2010, 78:446-452

24. Kolz M, Johnson T, Sanna S, Teumer A, Vitart V, Perola M, Mangino M, Albrecht E, Wallace C, Farrall M, Johansson A, Nyholt DR, Aulchenko Y, Beckmann JS, Bergmann S, Bochud M, Brown M, Campbell H, EUROSPAN Consortium, Connell J, Dominiczak A, Homuth G, Lamina C, McCarthy Ml, ENGAGE Consortium, Meitinger T, Mooser V, Munroe P, Nauck M, Peden J, et al: Meta-analysis of 28,141 individuals identifies common variants within five new loci that influence uric acid concentrations. PLoS Genet 2009, 5:e1000504.

25. Cappuccio FP, Strazzullo P, Farinaro E, Trevisan M: Uric acid metabolism and tubular sodium handling: results from a population-based study. JAMA 1993, 270:354-359.

26. Collazo R, Fan L, Hu MC, Zhao H, Wiederkehr MR, Moe OW: Acute regulation of $\mathrm{Na}^{+} / \mathrm{H}^{+}$exchanger NHE3 by parathyroid hormone via NHE3 phosphorylation and dynamin-dependent endocytosis. J Biol Chem 2000, 275:31601-31608

doi:10.1186/ar3769

Cite this article as: Hui et al:: The independent association between parathyroid hormone levels and hyperuricemia: a national population study. Arthritis Research \& Therapy 2012 14:R56.

\section{Submit your next manuscript to BioMed Central and take full advantage of:}

- Convenient online submission

- Thorough peer review

- No space constraints or color figure charges

- Immediate publication on acceptance

- Inclusion in PubMed, CAS, Scopus and Google Scholar

- Research which is freely available for redistribution

Submit your manuscript at www.biomedcentral.com/submit
C Biomed Central 